\title{
NOTES ON THE BIOLOGY OF SERTULARIA ARGENTEA L.
}

\author{
By D. A. Hancock, R. E. Drinnan and W. N. Harris \\ Fisheries Laboratory, Burnham-on-Crouch, Essex
}

(Text-figs. I-5)

A fishery has developed in recent years in this country for certain hydroids collectively termed 'white weed'. The hydroids, particularly Sertularia and, more recently, Hydrallmania, are raked up from the sea-bed, processed, dyed and used, largely in the United States of America, for decorative purposes. Fishing for white weed is not new, for it was practised in Germany between the wars. German scientists, notably von Reitzenstein (I9I3), Pax (I928), and Thiel (1938), examined various aspects of the fishery, and of biology of the hydroids concerned.

The main centre of the industry is the Thames Estuary, where the hydroids grow in extensive beds, on a bottom of sand and shells, on which the weed can be fished commercially by boats equipped with simple iron rakes.

\section{TAXONOMY}

There has been some difference of opinion on the naming of the various species among the Sertulariidae. The two species concerned in this work were first named by Linnaeus (I758) as Sertularia cupressina and S. argentea. $\mathrm{He}$ subsequently renamed them ( 1767$) S$. cupressina and $S$. cupressina var. $\beta$ argentea. Since then various authors, including Hincks (1868), have maintained their independence, while others, notably Broch (I9I8), followed by Kramp (1938) and Leloup (1938), have placed them together as S. cupressina. Broch (I9I8) considered that Hincks's (I868) distinction between the two species was based on characters which show too much variation. He later (1928) referred to them as S. cupressina forma typica (Broch) and S. cupressina forma argentea (L.). Von Reitzenstein (I9I3) followed Hincks (I868), and throughout his description of the hydroid used in the German whiteweed fishery used the name $S$. argentea (Ellis \& Solander, I786). Thiel (1938), however, figured and described the same species as $S$. cupressina, basing his description on that of Broch (I928). Others, including Nutting (I904) and McLean Fraser (1944), have removed them as separate species to the genus Thuiaria Fleming, the distinction between Sertularia and Thuiaria being the arrangement of the hydrothecae, which are in opposite pairs in Sertularia and alternate in Thuiaria. 
It is not proposed to discuss the case for a change of genus in this paper, but it is important to diagnose correctly the organisms concerned in the whiteweed fishery, particularly when referring to aspects of their biology and ecology.

The hydroid occurring in great quantity in the Thames Estuary, and used for preference in the whiteweed industry, is Sertularia argentea $\mathrm{L} .=S$. argentea Ellis \& Solander sec. Hincks (I868). This is easily distinguishable from Sertularia cupressina L. sec. Hincks (I868), and there seems to be no good reason why they should be considered to be the same species. Since this paper is mainly concerned with only one of these two species, this seems to be a good opportunity to emphasize their outstanding differences.

In the Thames Estuary, although most of the weed is normal S. argentea, there appears with it, in smaller proportion, a distinct form which has an altogether more luxuriant bushy growth. This form, which we shall call for convenience the 'bushy type', is easily distinguished by fishermen, and is less acceptable to the processers, who prefer to have many colonies per unit weight. The fresh weed is bought from the fishermen by weight and sold, when processed, as bunches of colonies. This bushy form shows no anatomical differences from the normal type, with the exception that the side branches are more subdivided and greatly elongated, as though the colony has been subjected to better growth conditions (Fig. I F, K). The proportion of bushy type Sertularia is small in winter and spring, but larger in summer and early autumn; it may therefore be a more luxuriant growth form produced from the normal type under summer conditions. However, in early winter, when much less of this type is found, long colonies of the normal-type Sertularia are still much in evidence, with no signs of any previous extension of their side branches. At the growing point the structure of the bushy form is identical with that of the typical $S$. argentea. Reference to Fig. I will leave little doubt that these are merely growth forms of the same species.

In North Wales there is another Sertularian, so far not observed in the Thames Estuary, which agrees closely with Hincks's (1868) account of $S$. cupressina. Superficially, in growth form, it resembles the bushy type of $S$. argentea, and is probably less suitable for commercial purposes. It is characteristic of fairly exposed sand-banks off the North Wales coast, and with it occurs, in smaller quantity, some $S$. argentea, mostly of the bushy type. In the Menai Straits, towards the eastern end, S. argentea, normal type, occurs predominantly with only a little $S$. cupressina. All three forms have been separated easily by untrained fishermen in North Wales.

In Fig. I are compared the growth forms of the two species, which differ markedly. The woodcuts in Hincks are excellent representations of the two species, but in all the specimens we have seen, the apex of $S$. argentea has been more tapering than that of $S$. cupressina (Figs. IA, E; 2). This could be attributed to variation in growth rates at different times between the two 

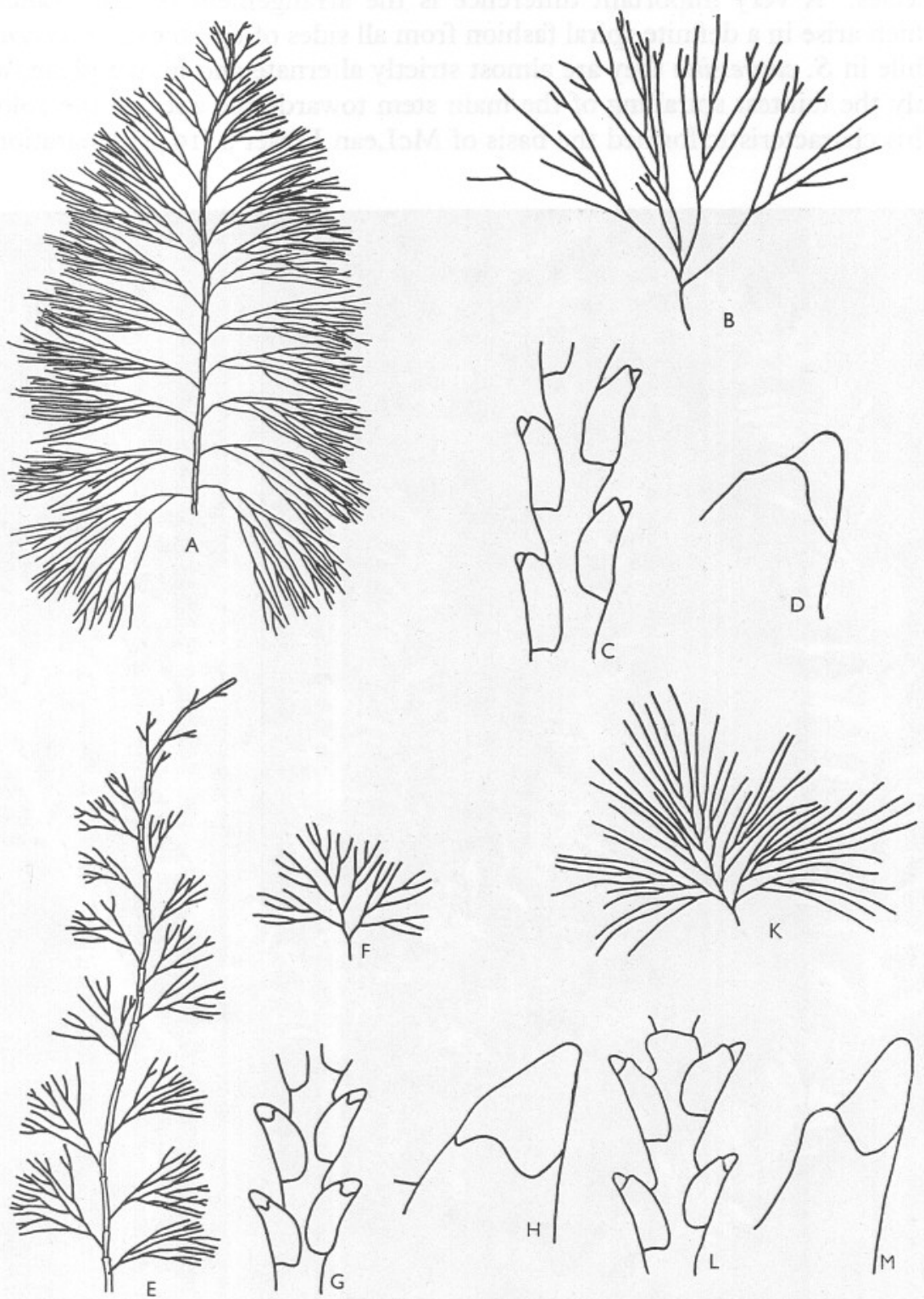

Fig. I. Outline drawings showing the morphology of Sertularia. A-D, S. cupressina, North Wales; E-H, S. argentea (normal type), Thames Estuary; $\mathrm{K}-\mathrm{M}, S$. argentea (bushy type), Thames Estuary. A, E, show the arrangement of the side branches on the main axis, $\times \frac{3}{4}$; $\mathrm{B}, \mathrm{F}, \mathrm{K}$, the subdivision of the side branches, $\times \mathrm{I}_{\frac{1}{4}} ; \mathrm{C}, \mathrm{G}, \mathrm{L}$, the hydrothecae on the side branches, $\times 25$ and $\mathrm{D}, \mathrm{H}, \mathrm{M}$, the hydrothecal margins, $\times 125$. 
species. A very important difference is the arrangement of the branches, which arise in a definite spiral fashion from all sides of the stem in S. argentea, while in S. cupressina they are almost strictly alternate and in one plane, with only the faintest spiralling of the main stem towards the apex of the colony. This characteristic formed the basis of McLean Fraser's (1944) separation of

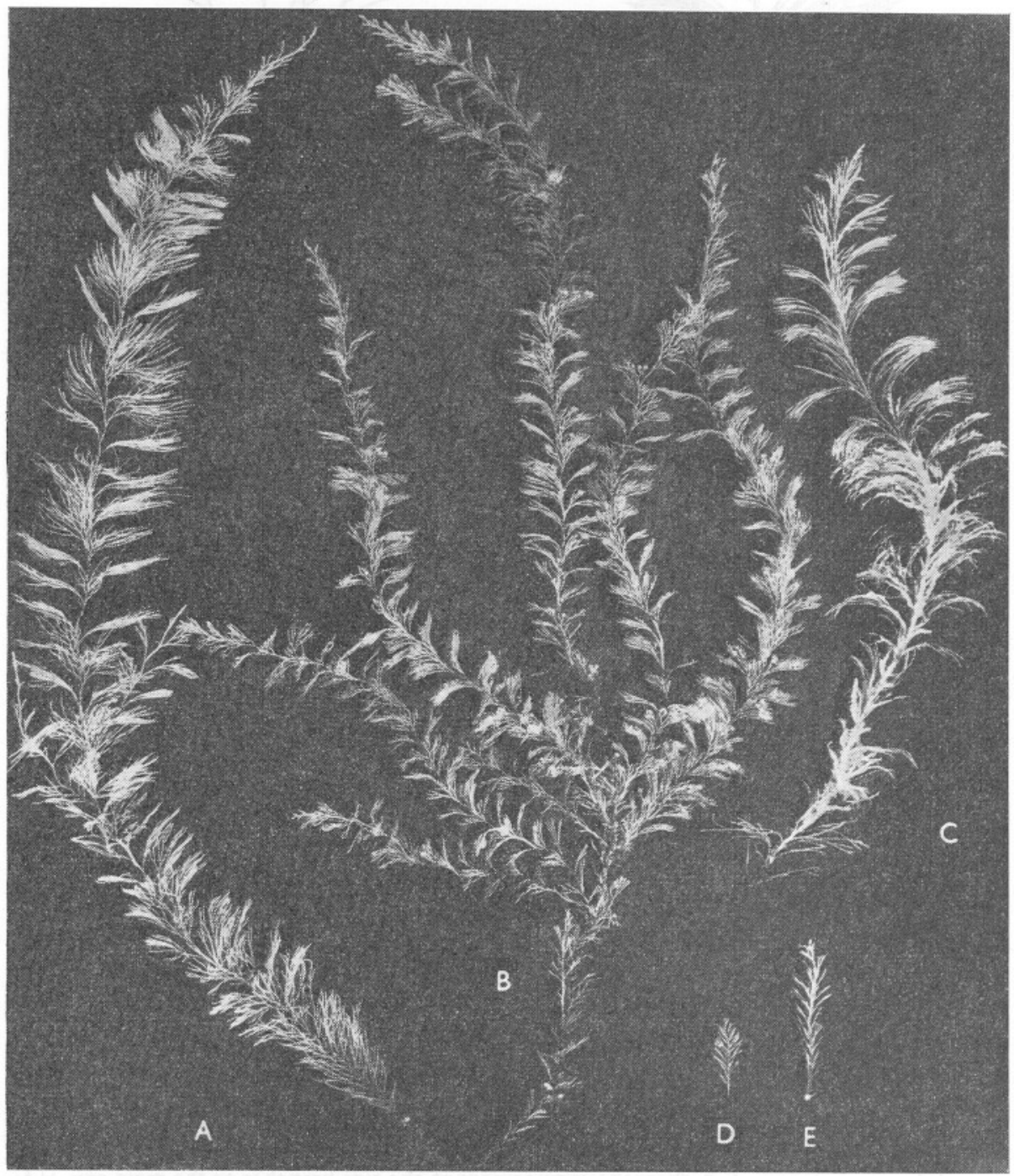

Fig. 2. A, S. argentea, bushy type, Thames Estuary; B, S. argentea, normal type, Thames Estuary; c, S. cupressina, North Wales; D, E, S. argentea, two young colonies. $\times \frac{1}{2}$. (Photo: R. Elms.) 
the two species. Broch (1928) was also aware of it when he described the two forms of $S$. cupressina. In $S$. cupressina the internodes are well defined, each bearing two opposite branches, rarely one or three, and a pair of opposite hydrothecae. Variations from two branches per internode can usually be explained by previous breakage or change in direction of growth of the colony. In $S$. argentea, each internode of the stem bears only one branch, rarely two, and several, usually two or three, opposite pairs of hydrothecae. It is interesting to note that in the young forms of $S$. argentea, on the first few centimetres of stem, the branching is in one plane, with usually two branches to each internode as in S. cupressina (Fig. 2). In Hincks's and von Reitzenstein's accounts, $S$. argentea is said to have two branches to each internode, but they may have been referring to the older part of the colony near the base; the branches are subdivided by regular dichotomy (Fig. IF), and stand out rigidly from the stem. The side branches of $S$. cupressina are less regularly subdivided, and more elongated, giving the whole colony a more graceful appearance. The elongation of the side branches of $S$. argentea, bushy form, is responsible for the superficial likeness between it and $S$. cupressina. The slenderness of the pinnules in $S$. cupressina is emphasized by the position of the hydrothecae, which are alternate and each is adnate throughout most of its length (Fig. IC). The apices of the hydrothecae are less divergent than in S. argentea. The hydrothecae of $S$. cupressina have a more open alternate arrangement, whereas in $S$. argentea it would be more correct to describe the hydrothecae as subopposite (Fig. I G). In $S$. cupressina the apex of each hydrotheca is produced into two almost equal teeth, but in $S$. argentea, the teeth are unequal (Fig. I D, H, M).

It is agreed with Broch (I9I8) that slight variations in the arrangement and form of the hydrothecae are found in a single colony, particularly between parts of different age, and for this reason less importance has been attached to them in the separation of the two species. The differences described were, however, evident when examining strictly comparable parts of colonies of similar size of the two species.

These differences in the characters of the two species are sufficient for easy separation and justify their maintenance as separate species.

For completeness, the characters of the two species are here listed partly after Hincks (1868) and McLean Fraser (1944).

\section{Sertularia argentea $\mathrm{L}$.}

Colonies usually up to $30-40 \mathrm{~cm}$, sometimes much longer and greatly branched. Branches arise from all sides of the stem with 'bottle brush' effect, usually one branch to each internode, but in young colonies branching in one plane, two to each internode. Branches subdivided by regular dichotomy; hydrothecae usually subopposite, curved gradually outwards, margin with two teeth, one usually longer than the other; operculum of two flaps. 


\section{Sertularia cupressina L.}

Colonies usually up to $30-35 \mathrm{~cm}$, occasionally much longer, branches regularly alternate, on opposite sides of stem only, usually two branches to each internode, upper part of stem may be faintly spiralled. Branches subdivided alternately rather than dichotomously; hydrothecae alternate, tubular, largely immersed and not strongly turned outward, margin with two almost equal teeth; operculum of two flaps.

\section{REPRODUCTION}

Hincks (I868) and Nutting (1904) have given a general account of reproduction throughout the Sertulariidae. Von Reitzenstein (1913) has described the reproduction of $S$. argentea L. in German waters. Teissier (1923) described the development and structure of the gonangia in Dynamena pumila (L.).

The multiplication of polyps to form a colony might equally be considered as growth or asexual reproduction. A second method of asexual reproduction is by the ramification of the stolon over the substrate from the basal disc. When a colony is removed from the substrate it is usually found to be attached to the bases of several others. This condition could result from planulae settling among the stolon extensions of one hydroid, or from the uniting of runners from several. It can, however, be seen to result, at least in part, from the formation of small colonies at the tips of the runners. (When colonies are encrusted by other organisms treatment with acid helps to reveal details of structure.) Von Reitzenstein (I9I3), too, suggested that this might be a form of asexual reproduction, exhibited most often at the end of the sexual period.

The most important form of reproduction is sexual. Vase-shaped gonangia, slightly flattened in a plane at right angles to the direction of the branch, are produced from the side branches, nearly perpendicular to the plane of the hydrothecae (Fig. 3). The fully developed gonangium is about $\mathrm{I} \mathrm{mm}$ in length. The branches bearing gonangia commence at a variable distance from the base, depending on the size and age of the colony, and extend to within a few $\mathrm{cm}$ of the apex. On an established breeding colony the youngest gonangia are found on the uppermost branches and towards the tips of those lower down. The most mature gonangia are usually more distant from the apex.

Thiel (1938) followed van Beneden (I866) and Goette's (1907) descriptions of the development of the female gonangium. He did not, however, describe the development of the male sex products, and disregarded von Reitzenstein's (I913) figure of the male gonotheca as being without foundation or description. Thiel's (1938) dogmatic statements, based, it seems, on the observations of other workers, concerning von Reitzenstein's work on breeding, are misleading, and it was not until after much of this work had been completed that it was found that several of von Reitzenstein's observations had been confirmed. 


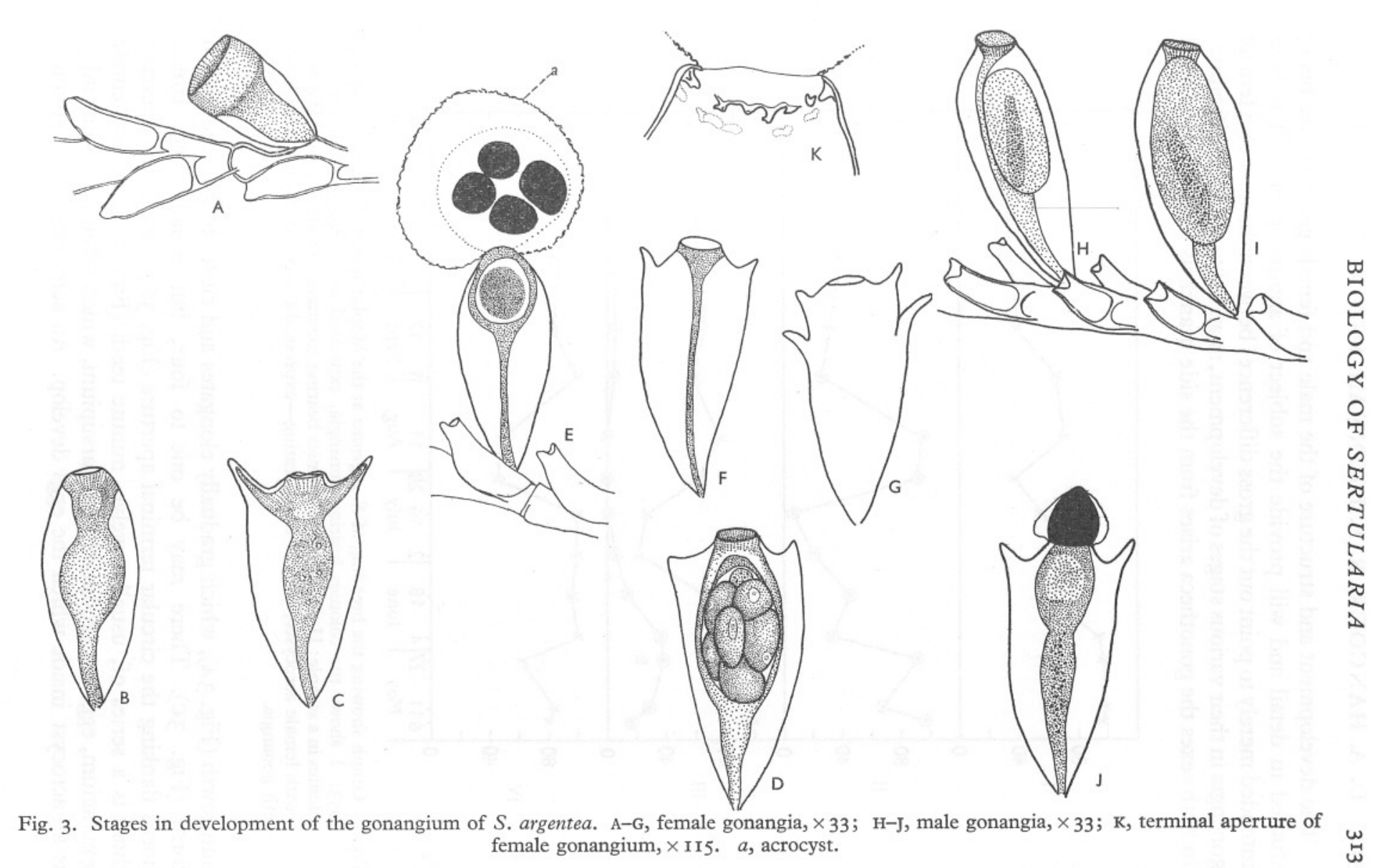


The development and structure of the male and female gonangia are being studied in detail and will provide the subject of another paper. It is here intended merely to point out the gross differences between the male and female gonangia in their various stages of development, as an aid to their identification. In both sexes the gonotheca arises from the side branch as a small cup-shaped

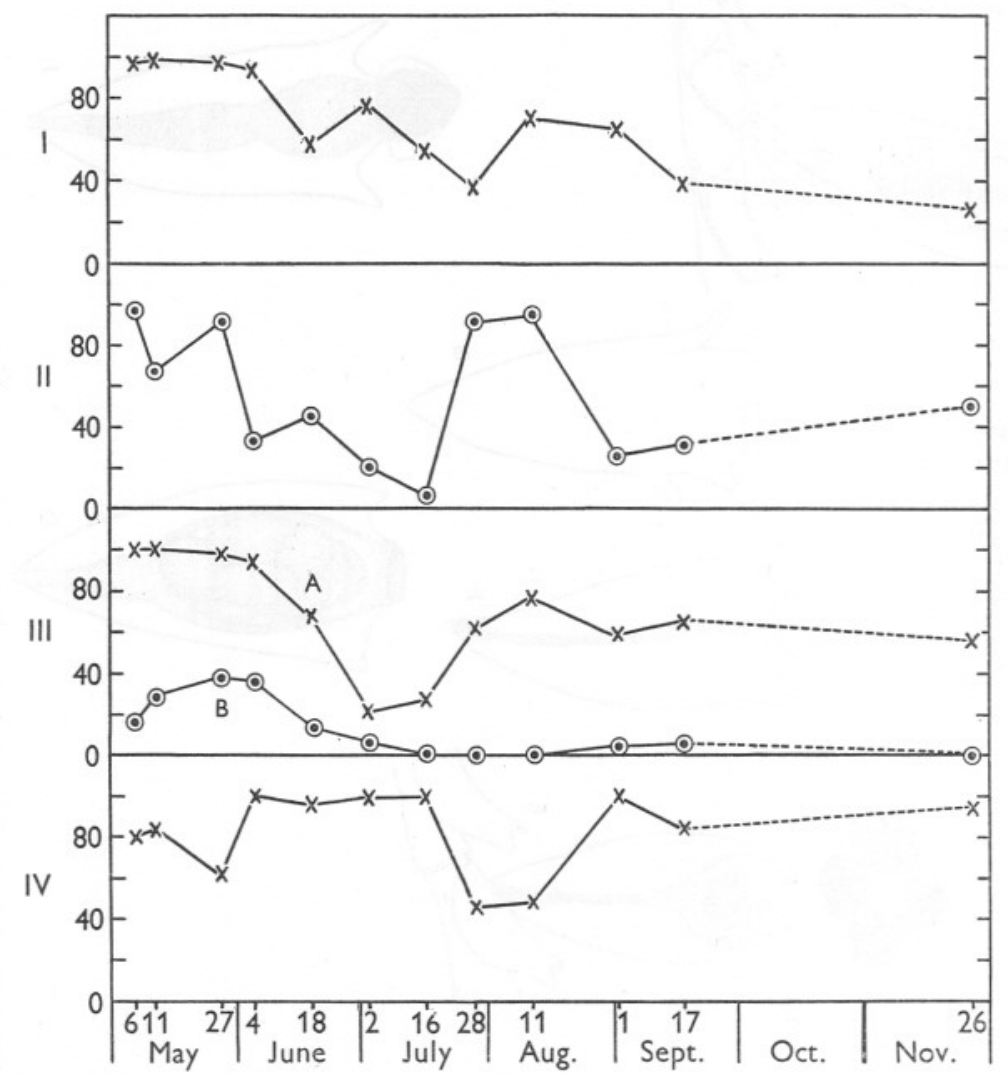

Fig. 4. Graph showing the breeding of $S$. argentea at the Maplin Sands, Thames Estuary, in I953. I shows the colonies bearing gonangia, expressed as a percentage of the total colonies in a sample; II-IV show the colonies bearing gonangia-II developing, III A ripe, B with female acrocysts; and IV degenerating-expressed as a percentage of the colonies with gonangia.

outgrowth (Fig. 3A), which gradually elongates and closes to give the typical form (Fig. 3C). There may be one to four, but usually two, lateral horns flanking the circular terminal aperture (Fig. 3G). Inside the aperture there is a series of, usually twelve, minute teeth (Fig. $3 \mathrm{~K}$ ). In the female gonangium, eggs are produced in a marsupium, which when ripe is extruded as an acrocyst inside which the eggs develop. An acrocyst usually contains 
from two to ten eggs which develop into planulae. Rupture of the acrocyst allows the escape of the planulae (Fig. 5 B).

The stages of development of a gonangium are distinguishable (Fig. 3) in fresh material under a microscope. Initially the contents are restricted to an only slightly swollen longitudinal band, enlarged terminally to fill the horns and apex of the gonotheca. Subsequently, the gonotheca becomes full when nearly ripe. In degenerating stages the gonothecae are empty, or contain a narrow strip of tissue slightly enlarged near the aperture. The ripe female gonangium is easily recognized by its content of regularly shaped pink ova, or by the presence of an acrocyst containing developing eggs. The ova can be distinguished at an early stage in the development of the female gonangium.
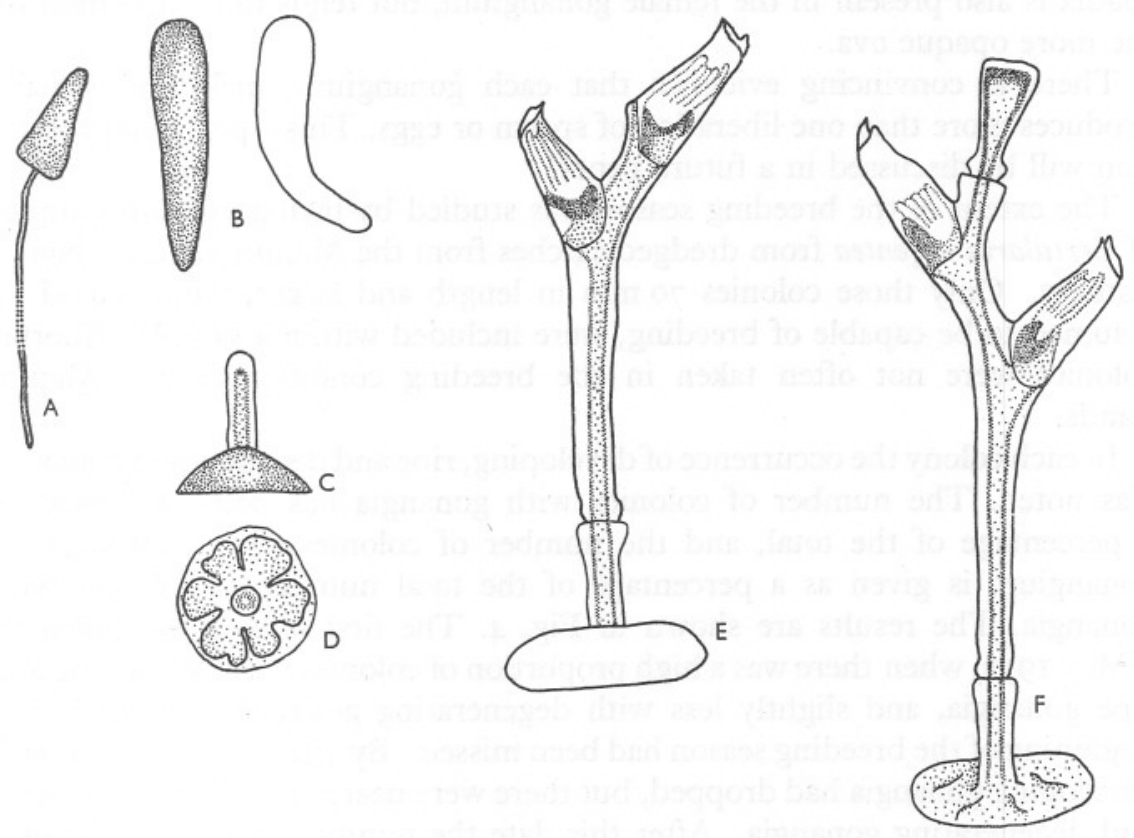

Fig. 5. Early development of $S$. argentea. A, a single sperm; B, planula; C, D, newly settled colony; E, F, after formation of the first few hydrothecae. $\mathrm{A}, \times 4,500 ; \mathrm{B}-\mathrm{F}, \times 50$.

Smears of ripe gonangia from certain colonies carrying developing, mature and degenerating gonangia, but no acrocysts, showed developing and ripe sperm (Fig. 5A). These gonangia were all creamy white, in contrast to the pinkness of the full gonangia of colonies bearing acrocysts. In a study of many colonies, no male gonangium was found on a colony with female acrocysts, nor any female acrocysts on colonies with gonangia containing spermatozoa. It was concluded that there are separate male and female colonies, readily separable when ripe by the colour of the gonangia. Subsequently, the male 
colonies have been found with a form of acrocyst protruding from the gonangia, but here it is smaller, densely white and full of mature spermatozoa (Fig. $3 \mathrm{~J}$ ). The male 'acrocyst' has a thin membrane enclosing the sperm, and is less regularly round than that of the female. It seems to be a more transient structure, less likely to be found.

In fresh specimens the sexes can be readily separated by the colour of the ripe gonangia. A further aid to identification of the male is the presence of a dark reddish brown band of pigment, the spadix, which is readily seen in developing male gonangia within a regularly oval translucent sac. This is less easily seen when the ripe gonangium is filled by sperm (Fig. $3 \mathrm{H}, \mathrm{I}$ ). The degenerating male and female gonangia are very similar. A reddish brown spadix is also present in the female gonangium, but tends to be obscured by the more opaque ova.

There is convincing evidence that each gonangium, male and female, produces more than one liberation of sperm or eggs. This aspect of reproduction will be discussed in a future paper.

The extent of the breeding season was studied by taking random samples of Sertularia argentea from dredged catches from the Maplin Sands, Thames Estuary. Only those colonies $70 \mathrm{~mm}$ in length and larger, which could be assumed to be capable of breeding, were included within a sample. Shorter colonies were not often taken in the breeding condition on the Maplin Sands.

In each colony the occurrence of developing, ripe and degenerating gonangia was noted. The number of colonies with gonangia has been expressed as a percentage of the total, and the number of colonies with each stage of gonangium is given as a percentage of the total number of colonies with gonangia. The results are shown in Fig. 4. The first sample was taken on 6 May I953, when there was a high proportion of colonies with developing and ripe gonangia, and slightly less with degenerating gonangia. Evidently the beginning of the breeding season had been missed. By 4 June the number with developing gonangia had dropped, but there were nearly $100 \%$ with both ripe and degenerating gonangia. After this date the number with ripe gonangia became less. After a slight increase, the percentage with developmental stages also declined until towards the end of July when a second maximum of colonies with developing gonangia was found. This was followed in mid-August by a peak in the percentage with ripe gonangia and, in early September, by a peak in the number with degenerating gonangia. Although the colonies bearing gonangia formed a high percentage of the total colonies at the time of the first breeding maximum in May/June, their number decreased in July, corresponding with the falling off in the number of colonies with developing and ripe gonangia, and increased only slightly for the second breeding peak in July/August. Thus the second burst of breeding is less intense. Although, in November, the proportions of gonangia-bearing colonies with developing 
and ripe gonangia were high, yet only $25 \%$ of all colonies carried gonangia, so that the total amount of breeding was small.

These observations were made from preserved samples and no attempt was made to distinguish the sexes, but where colonies bearing female acrocysts were present they were noted, and their number expressed as a percentage of the total colonies with gonangia. These reached a maximum in late May. It was later found that the sexes could be quickly distinguished in preserved colonies by dehydrating a mature side branch and examining it in a clearing agent.

To estimate how much earlier than 6 May the breeding season had commenced, ten randomly selected colonies from each of the first three samples were examined more closely, and the stages of the gonangia from every fifth branch counted and recorded. To count and identify the gonangia on every branch would have taken much time; the total number of gonangia on several colonies was therefore counted, and the proportion of each stage compared with the results of counting every fifth branch. This gave a reasonably accurate comparison. The three groups distinguished were: I, early developmental (without horns); II, late developmental and ripe; and III, degenerating; their numbers have been expressed as a percentage of total gonangia in Table I. It seems that the gonangia must first appear during April, but the position of the peak of ripe gonangia at the beginning of June is confirmed (Fig. 4).

\section{Table I. The Percentages of Three Stages of Gonangia IN SERTULARIA ARGENTEA}

I developing, II ripe, III degenerating, counted on every fifth branch from the colonies in samples from the Maplin Sands in I953.

$\begin{array}{cccc}\text { Date } & \text { I } & \text { II } & \text { III } \\ \text { 6 May } & \text { 2I } & 4 \text { I } & 38 \\ \text { 27 May } & \text { I } 4 & 58 & 28 \\ \text { 4 June } & \text { I } & 69 & 30\end{array}$

The distribution of the various stages in the development and degeneration of the gonangia on a colony was also confirmed by these counts. For example, from the sample of 27 May I953, a female colony of $420 \mathrm{~mm}$ length carried the gonangia shown in Table II, with the youngest gonangia towards the apex and the oldest lower down. Below the eightieth branch from the apex there were a few additional branches, then a region of $60 \mathrm{~mm}$ devoid of branches, a usual condition in older colonies.

Von Reitzenstein (1913) found that the breeding period of S. argentea in Germany in 1908-9 extended from April to early June, and that when the spawn was released, the empty gonangia fell off. At the beginning of July he could find no more colonies with gonangia; there followed in August a second less important reproductive period when a smaller proportion of colonies 
carried gonangia. This second breeding period lasted until November when an occasional colony was taken with gonangia, but none in winter.

There is some evidence that the breeding period may vary in length on whiteweed grounds separated by only a few miles. For example, in a sample taken from near West Buxey, about 4 miles from the Maplin Sands, on 25 November I953, $78 \%$ of the colonies bore gonangia, and $28 \%$ of the colonies with gonangia carried acrocysts. This was quite a different picture from that obtained on the Maplin Sands (Fig. 4). Occasional colonies with female acrocysts or male gonangia with developing and ripe spermatozoa have been taken throughout the winter months, but the great majority have none.

\section{Table II. The Numbers of Gonangia on each Fifth Side Branch OF A 420 MM COLONY OF SERTULARIA ARGENTEA}

The stages are I early developmental, II ripe, III degenerating gonangia.

$\begin{array}{cccc}\begin{array}{c}\text { Branch, } \\ \text { numbering } \\ \text { from apex }\end{array} & \overbrace{}^{\text {I }} & \text { II } & \text { III } \\ 0 & - & - & - \\ 5 & \text { Stage } & - & \text { 二 } \\ \text { I0 } & - & - & - \\ 15 & \text { I6 } & 78 & - \\ 20 & \text { I6 } & 55 & 6 \\ 25 & - & 67 & \text { I } \\ 30 & - & 61 & 28 \\ 35 & - & 38 & 16 \\ 40 & - & 8 & 10 \\ 45 & - & 13 & 4 \\ 50 & - & 1 & 3 \\ 55 & - & 3 & 5 \\ 60 & - & - & 2 \\ 65 & - & - & - \\ 70 & - & - & - \\ 75 & & & \end{array}$

The developing eggs within the acrocysts are about $40-50 \mu$ in diameter. Typically the head of each spermatozoan is an elongated triangle (Fig. 5A), 2-3 $\mu$ long and I-I.5 $\mu$ wide, with a tail 30-40 $\mu$ long.

\section{DEVELOPMENT}

Rupture of the acrocyst allows escape of the ciliated planulae, each of which assumes an elongated form, about $0.5 \mathrm{~mm}$ in length, with a somewhat blunt anterior end (Fig. 5B). The planula revolves with a forward swimming, creeping motion. In the laboratory the planulae were not seen to swim near the surface, but remained near the bottom. It seems likely that they are confined to the bottom and are not pelagic. This would increase the tendency for the hydroids to form a dense covering of the substrate, and would lead to 
the formation of fairly discrete beds, as observed. Hydrographic conditions would clearly exert a considerable influence.

The settlement of the planulae and early development of the colony have been followed in the laboratory. The planula attaches to the substrate, usually a piece of shell or stone, and produces a semi-spherical holdfast-irregularly lobed when viewed from above (Fig. 5C, D). The planulae under observation hatched from acrocysts placed in an aquarium on 8 May I954. By II May they had assumed the form shown in Fig. 5C. This agrees with von Reitzenstein's (I9I3) estimate of a free swimming period of 2-3 days. By I7 May elongation of the main stem had occurred with a node near the base, and the first two polyps, each fully furnished with a hydrotheca, had been formed. On 20 May, young colonies with three polyps were observed, but after this date development ceased, due to some unfavourable condition, and the young colonies died (Fig. 5E, F). Under laboratory conditions, the initial growth to a length of less than $2 \mathrm{~mm}$ took almost 2 weeks. The settlement and early growth of Dynamena pumila (L.) have been described by Teissier (1923).

\section{GROWTH}

Several attempts have been made to observe the growth rate of $S$. argentea throughout the year in the Thames Estuary. Shells bearing Sertularia were dredged, some colonies measured, and the shells attached to concrete blocks which were buoyed, or attached to beacons, and returned to the sea bottom. These experiments were of short duration because the concrete blocks and shells were frequently lost or buried by shifting sand in bad weather. It was found difficult to keep colonies of Sertularia alive in the laboratory conditions for long enough to observe growth rates. It is believed that excessive silt in the water supply, due to bad weather, was responsible. The most successful method was to suspend the colonies from a piece of cord stretched across a large tank filled with sea water, shaking the cord periodically to dislodge the silt. The results available from the laboratory, the River Crouch and the Maplin Sands, are given in Table III. In the field quite young colonies were used and the growth rate varied from 0.3 to $\mathrm{I} \cdot 3 \mathrm{~mm}$ per day. This agreed closely with the measurements of growth in the laboratory in which the average increment varied between $0 . \mathrm{I}$ and $\mathrm{I} \cdot 7 \mathrm{~mm}$ per day. An attempt is being made to study the growth rate in the Thames Estuary throughout the year in 1955 . The majority of colonies attached to blocks showed negligible growth during February, the maximum recorded being $6 \mathrm{~mm}$ in 28 days-that is $0.2 \mathrm{~mm}$ per day. During March all but a few colonies showed growth, and a maximum of $0.4 \mathrm{~mm}$ per day was recorded.

Von Reitzenstein (I9I3) found that growth was not continuous throughout the year. The peak of growth (four-fifths of the total) occurred in the months of May to September. His results for Sertularia grown in culture boxes in the 
TABLE III. Growth of SERTULARIA ARGENTEA

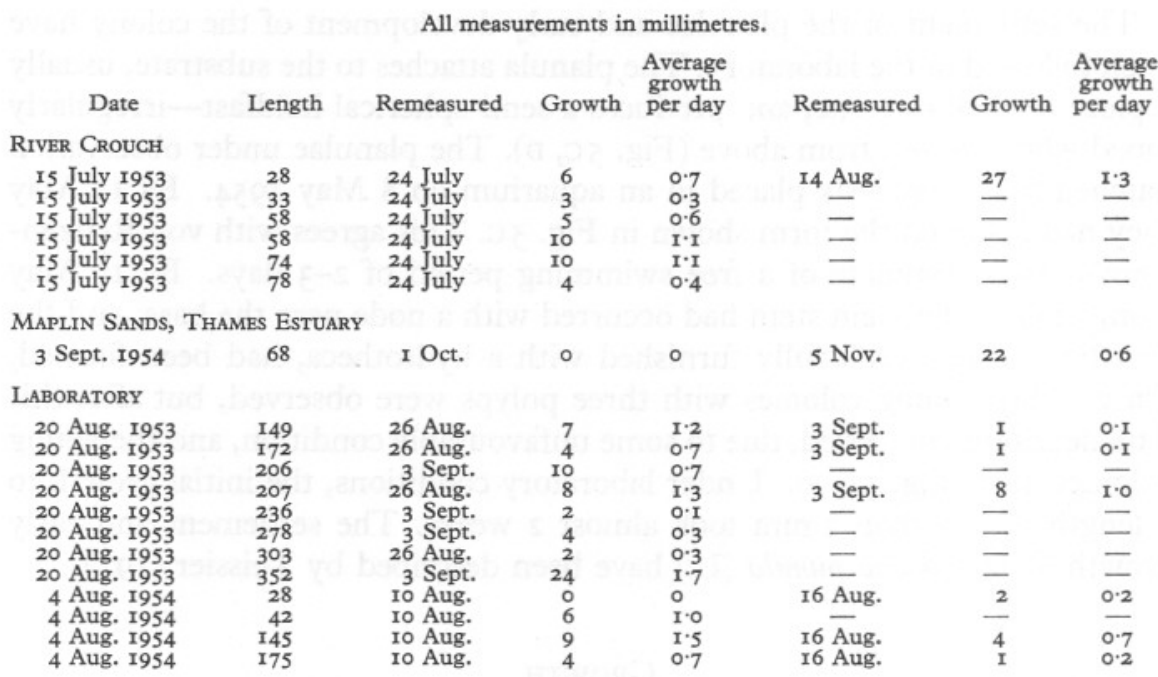

sea at Hörnum in 1908 may be summarized as follows, all measurements being in $\mathrm{mm}$ :

\begin{tabular}{|c|c|c|c|c|}
\hline \multirow[b]{2}{*}{ Growth period } & \multicolumn{2}{|c|}{ Average growth } & \multicolumn{2}{|c|}{ Maximum growth } \\
\hline & $\begin{array}{l}\text { Over the } \\
\text { period }\end{array}$ & $\begin{array}{l}\text { Average } \\
\text { per day }\end{array}$ & $\begin{array}{l}\text { Over the } \\
\text { period }\end{array}$ & $\begin{array}{l}\text { Average } \\
\text { per day }\end{array}$ \\
\hline Io Apr.-20 May 1908 & $3 \cdot I$ & 0.05 & I0.0 & 0.24 \\
\hline 2I May-9 July I908 & $12 \cdot 5$ & 0.25 & $30 \cdot 0$ & 0.60 \\
\hline IO July-I2 Sept. I908 & $50 \cdot 0$ & 0.77 & $80 \cdot 0$ & $\mathrm{I} \cdot 25$ \\
\hline I2 Sept.-4 Nov. I908 & $26 \cdot 2$ & 0.50 & $40 \cdot 0$ & 0.75 \\
\hline 5 Nov. -26 Mar. I909 & $10 \cdot 0$ & 0.07 & $15 \cdot 0$ & 0.15 \\
\hline
\end{tabular}

He also cultured Sertularia in the sea on a board and on a basket lid, from May to November of the same year. By both these methods the growth rate in the summer months was greater than by the box method. Combining all his results, he arrived at the figure of $228.4 \mathrm{~mm}$ average growth and $285.0 \mathrm{~mm}$ maximum growth between Io April 1908 and 26 March 1909.

Von Reitzenstein's growth rates are of the same order as those obtained for the Thames Estuary. The difficulties of obtaining growth measurements have been described; von Reitzenstein's results are open to the criticism that he included many colonies of different sizes which may well have had quite different growth rates, and further, the results were not based on the same colonies over the whole period. Von Reitzenstein himself, however, was aware of the weaknesses in his methods. Thiel (1938), commenting on von Reitzenstein's results, stated that the growth recorded must have been much lower than that occurring under natural conditions, but gave no reasons for this 
opinion. The maximum growth recorded by von Reitzenstein between Io July and I2 September 1908 averaged I $\cdot 7-\mathrm{I} \cdot 8 \mathrm{~mm}$ per day, which agrees closely with our maximum growth increment which averaged $\mathrm{I} \cdot 7 \mathrm{~mm}$ per day during August to September 1953 under as near as possible natural conditions.

It is felt that von Reitzenstein's estimate of about $26 \mathrm{~cm}$ annual growth in the sea is not unreasonable. He also gave an indication of the slowing of growth rate with increase in size of a colony. His conclusion that the largest colonies of 60-70 cm length were 2-3 years old was based on the assumption that large and small colonies have the same rate of growth.

Von Reitzenstein also found that colonies cast off branches and side branches in winter when growth virtually ceased. This process is responsible for the lack of side branches in the lower regions of older colonies. Eichelbaum (I9I2) found that whole colonies, usually those over $30 \mathrm{~cm}$, became detached in autumn, and concluded that some dispersal of the species was effected when the colonies, covered by gonangia, were carried away by currents.

\section{REGENERATION}

From the fishery aspect the question of regeneration is of great importance. In a sample of white weed taken from a commercial rake it was found that only $16 \%$ of the colonies had been taken with their basal discs intact. The stems of the remainder had been broken just above the base, some across obviously living white stem, others across the dark thickened lower stem close to the point of attachment, a region which has little appearance of being alive.

Using methods similar to those described on growth studies it was found that colonies cut at all levels and returned to the sea were capable of regeneration, even those cut through the blackened region close to the basal disc. Regeneration of the latter was usually by small white sprouts appearing near the cut ends, while in the remainder a continuation of the terminal growth took place. In July 1953 the rate of regeneration by this method was found to vary between 0.1 and $\mathrm{I} \cdot 4 \mathrm{~mm}$ per day (Table IV).

Since cut blackened bases of Sertularia colonies are capable of regenerating in this way, it seems likely that the holdfast of a cut colony can also continue to bud vegetatively from the stolon as described earlier (p. 312).

In order to discover whether side branches lost at the approach of winter are capable of becoming attached to form new colonies, several side branches were detached from a mature colony and attached vertically to a glass plate, held in a laboratory tank with running sea water. The experiment was continued from I to 2I September 1954, and although none of the side branches produced a holdfast, most of them had begun growing from the cut end. One had produced two small branches, each with four opposite pairs of hydrothecae, and most of the others were growing in a similar way, but nothing 
resembling a basal disc or stolon was produced. The experiment ended with the death of the branches, probably caused by excess of silt. Many young colonies have been inspected to see if any had an unusual growth form which might have resulted from the attachment of a side branch, but none was found. It is probable that when the side branches are lost the polyps and tissues have been retracted and that they consist merely of skeletal matter, and would therefore be incapable of settlement. The retraction of tissue into the stolon of Dynamena (= Sertularia) pumila (L.) in autumn and winter, followed by the reforming of the polyps in the old thecae in January and February, has been described by Haddow (I936). It does not seem likely that the shedding of branches of Sertularia argentea constitutes a form of asexual reproduction. The experiment, however, demonstrated the remarkable powers of regeneration possessed by these hydroids.

\section{TAble IV. Regeneration of SERTUlaria ARGENTEA}

\begin{tabular}{|c|c|c|c|c|c|c|c|c|}
\hline & & & All measurem & ts in $\mathrm{mm}$ & & & & \\
\hline Date & Length & Cut to & Remeasured & Growth & $\begin{array}{l}\text { Average } \\
\text { growth } \\
\text { per day }\end{array}$ & Remeasured & Growth & $\begin{array}{l}\text { Average } \\
\text { growth } \\
\text { per day }\end{array}$ \\
\hline RIVER CROUCH & & & & & & & & \\
\hline I5 July I953 & 43 & 33 & 24 July & 4 & 0.4 & - & - & - \\
\hline I5 July I953 & 45 & I8 & 24 July & 3 & 0.3 & - & - & - \\
\hline Is July r 953 & 48 & 38 & 24 July & 2 & 0.2 & I4 Aug. & 22 & $\mathbf{r} \cdot \mathbf{O}$ \\
\hline I5 July I953 & 49 & 38 & 24 July & I & $0 \cdot I$ & - & - & - \\
\hline I5 July I953 & 60 & 38 & 24 July & 2 & 0.2 & - & - & - \\
\hline I5 July I953 & 65 & 38 & 24 July & $\mathbf{I}$ & 0.1 & I4 Aug. & 12 & 0.6 \\
\hline I5 July I953 & 65 & 48 & 24 July & 4 & 0.4 & I4 Aug. & 3 & 0.1 \\
\hline I5 July r953 & 75 & 43 & 24 July & 3 & 0.3 & - & - & - \\
\hline I5 July I953 & 80 & 48 & 24 July & 3 & 0.3 & I4 Aug. & 23 & $\mathbf{I} \cdot \mathbf{I}$ \\
\hline I5 July I953 & I Io & 63 & 24 July & 4 & 0.4 & - & - & - \\
\hline I5 July I953 & I58 & 70 & 24 July & 3 & 0.3 & - & - & - \\
\hline I5 July r953 & I58 & 108 & 24 July & I & 0.1 & - & - & - \\
\hline I5 July I953 & I8̊० & 158 & 24 July & 13 & $I \cdot 4$ & - & - & - \\
\hline I5 July I953 & I90 & I78 & 24 July & II & $I \cdot 0$ & - & 一 & - \\
\hline MAPLIN SANDS & & & & & & & & \\
\hline 3 Sept. I 954 & $2 I$ & 13 & I Oct. & 13 & 0.5 & 5 Nov. & I6 & 0.5 \\
\hline 3 Sept. I954 & 32 & 22 & I Oct. & 9 & 0.3 & 5 Nov. & I4 & 0.4 \\
\hline 3 Sept. I954 & 63 & 37 & I Oct. & 8 & 0.3 & & - & - \\
\hline 3 Sept. I954 & 69 & 39 & I Oct. & 4 & 0.1 & 5 Nov. & 8 & 0.2 \\
\hline 3 Sept. I954 & 98 & 48 & I Oct. & 29 & $I \cdot 0$ & & - & - \\
\hline 3 Sept. I954 & II8 & 33 & I Oct. & 8 & 0.3 & 5 Nov. & 7 & 0.2 \\
\hline
\end{tabular}

A number of colonies, both male and female, have been found bearing gonangia each with a small vegetative branchlet emerging from the mouth. Sometimes this new growth was branched several times, but more usually there was a simple stem with three or four hydrothecae. Dissection showed that in some the theca of each branchlet was continuous with the gonotheca, which contained an extension of the coenosarc. In others the new branch emerged from inside the gonotheca. The arrangement of hydrothecae on the new branches was found to be more like those of the remainder of the colony, than of a newly settled form. Each gonotheca was of adult dimensions, with horns, and contained an extension of the coenosarc continuous with that of the new growth. It seemed likely either that in the course of degeneration of the 
gonangium the coenosarc had grown through the gonotheca, or that the gonangium had aborted during its development and reverted to vegetative growth. The result was a number of small branchlets in the same plane as the gonangia, that is perpendicular to the normal direction of growth.

\section{Commensals and PRedators}

Sertularia and other hydroids provide a satisfactory habitat for a number of free and fixed epizoic forms. Most often associated with Sertularia are encrusting bryozoans, particularly Membranipora pilosa (L.), which may cover stems, branches and even gonothecae, obviously in some cases with harmful effects. One colony of length $510 \mathrm{~mm}$ was found to be covered from 70 to 4IO $\mathrm{mm}$ from its base by the bryozoan, and another of $280 \mathrm{~mm}$ was covered from 40 to $240 \mathrm{~mm}$. Up to $85 \%$ of the colonies in a sample of white weed taken from the Maplin Sands in August 1953 carried encrusting Bryozoa. A thickly encrusted main stem is often devoid of side branches, and shows the effects of severe competition and suffocation. The settlement of Bryozoa reduces the commercial value of white weed.

To a lesser extent encrustation by other hydroids such as Clytia johnstoni Alder, Tubularia sp. and Obelia spp. also occurs. Where present they often form a dense covering as do some peritrichous ciliates.

The larvae of several bivalves find a suitable settling place in the fronds of white weed, which may be found with many thousands of mytilid spat on their branches. Sertularia taken from Fleetwood in August I954 was in such a condition, and these accumulations of developing bivalves must be of great interest to demersal fish. From the Maplin Sands samples the largest numbers of bivalve spat were taken in July.

Sertularia also provides a home for a number of free-living forms, in particular, caprellids and pycnogonids. Caprella linearis (L.) may occur in abundance, up to an average of five per colony being taken on the Maplin Sands in July I953. Nymphon brevirostris Hodge occurs frequently, and it and the caprellids are hard to distinguish from the Sertularia because of their similar colouring. The nudibranch Idulia coronata (Gmel.) is frequently taken with its spawn.

It is questionable whether any of these animals feed directly on Sertularia. At certain times of the year the lower parts of the older colonies are devoid of branches. This might be due to the feeding of some predator. However, denuding of side branches is almost always confined to the lower part of the stem, and is more likely to be due to the annual decline of the colony towards the end of the year when the lower branches are shed. This has been described by von Reitzenstein (I9I3).

Colonies have also been taken regularly in which only the bases of certain side branches remained, covered by Bryozoa, while other branches were intact. 
Where a bryozoan was present at the base the rest of the branch was dead. This would also contribute towards the loss of side branches.

Of twenty flatfish taken from a whiteweed bed at Fleetwood in August 1954, only two dabs contained isolated fragments of Sertularia, which were amongst vast quantities of mussel spat in the stomach. The heavy settlement of mussel spat on Sertularia has been mentioned previously and the presence of the Sertularia was believed to be incidental.

Hunt (1925) took fragments of hydroids from the stomach of Leander, and Mistakidis (in press) has recorded occasional fragments of Sertularia from Pandalus.

Harrison (1944) mentions that several observers have maintained that caprellids feed on hydroids and algae, but that such an occurrence is probably exceptional. He found that caprellids fed on copepods and nauplii from the plankton. During frequent observations made by the writers caprellids were observed feeding in the manner suggested by Harrison and did not take Sertularia.

Idulia has not been observed feeding, but Browne (1907) has described the intensive feeding of Tergipes on Syncoryne.

It is considered unlikely that the exploitation of white weed can be substantially detrimental to commercial fisheries, while many fishermen believe that the constant harrowing of the sea-bed by the rakes is beneficial to the development of benthos generally, and of assistance to many fish during feeding.

\section{SUMMARY}

There has been considerable divergence of opinion on the naming of species of Sertularia. It is suggested that Linnaeus's (I758) original names S. cupressina and $S$. argentea relate to distinct species, which may be separated on certain anatomical characters, notably the manner of branching. The 'white weed' fished commercially in the Thames Estuary is S. argentea.

A study of the reproduction of $S$. argentea in the Thames Estuary showed that separate male and female colonies exist, and a general description of the development of the gonangia in both sexes is given. The main sexual breeding occurs in May and June, with a second, but less intense, period in July/August. The early growth, following settlement of planulae, was observed in the laboratory.

Measurements of growth were made in the field and laboratory. Growth is seasonal, occurring mostly in the summer months. A maximum growth of I.7 $\mathrm{mm}$ per day was recorded.

Examination of natural and experimental material showed that regeneration of cut stems is possible at all levels, and that even detached side branches can continue to grow to form new branches.

The main commensals and predators of $S$. argentea are mentioned with their possible effects on the host and the whiteweed industry. 


\section{REFERENCES}

Beneden, E. van, I866. Recherches sur la faune littorale de Belgique, Polypes. Mém. Acad. R. Belg. Cl. Sci., T. 36.

BRoch, H., I9I8. Hydroida (Part II). Dan. Ingolf-Exped., Vol. 5, pp. I-205. I928. Hydrozoa I. Tierwelt N.- $u$. Ostsee, Teil $3 b$, pp. I-IOo (Lief. I3).

BRownE, E. T., I907. A new method for growing hydroids in small aquaria by means of a continuous current tube: F. mar. biol. Ass. U.K., Vol. 8, pp. 37-43.

Eichelbaum, E., I9I2. Die Seemoosfischerei an der Kuste von Ostfriesland. Abh. dtsch. SeefischVer., Bd. I2, pp. 53-94.

Ellis, J. \& SolAnder, D., I786. The Natural History of many Curious and Uncommon Zoophytes collected from various parts of the Globe, $208 \mathrm{pp}$. London.

GoETTE, A., I907. Vergleichende Entwicklungsgeschichte der Geschlechtsindividuen der Hydropolypen. Z. wiss. Zool., Bd. 87, pp. I-335.

Haddow, A. J., I936. The growth of Sertularia. Rep. Scot. mar. biol. Ass., 1936-7, pp. 8-9.

HARrison, R. J., 1944. Caprellidea. 27 pp. London: Linnean Society.

Hincks, T., 1868. A History of the British Hydroid Zoophytes. 2 vols. London: John van Voorst.

Hunt, O. D., I925. The food of the bottom fauna of the Plymouth fishing grounds. F. mar. biol. Ass. U.K., Vol. 13, pp. 560-98.

Kramp, P. L., I938. Marine Hydrozoa. Hydroids. The Zoology of Iceland, Vol. 2, $82 \mathrm{pp}$.

Leloup, E., I938. Quelques Hydraires des Côtes orientale et occidentale. Mém. Mus. Hist. nat. Belg., T. I4, pp. I-9.

LinNaEus, C., I758. Systema Naturae. Ioth ed. Lipsaiae. I767. Systema Naturae. I2th ed. Holmiae.

McLean Fraser, C., 1944. Hydroids of the Atlantic Coast of North America. Toronto: University of Toronto Press.

Mistakidis, M. N. The biology of Pandalus montagui Leach. (In the Press.)

Nutring, C. C., 1904. American Hydroids. Part II. The Sertulariidae. Smithsonian Inst. U.S. Nat. Mus.

Pax, Ferdinand, 1928. Seemoos. Rohstoffe d. Tierreichs, Lief. I, pp. 9-29, Io text-figs.

Reitzenstein, E. von, I9I3. Das Seemoos und das Korallenmoos, ihre Fischerei, ihre Lebens. Abh. dtsch. SeefischVer., Bd. I2, pp. I-50.

Teissier, G., I923. Recherches sur Dynamena pumila (L.). Trav. Sta. biol. Roscoff, T. I, pp. I-59.

ThIEL, M. E., I938. Naturgeschichte des Seemooses. Handb. Seefisch. Nordeurop., Bd. 3, 34 pp. 